\title{
MIGRANT WORKERS IN THE MIDDLE EAST
}

ISSUE EDITORS

Prasannan Parthasarathi

Donald Quataert
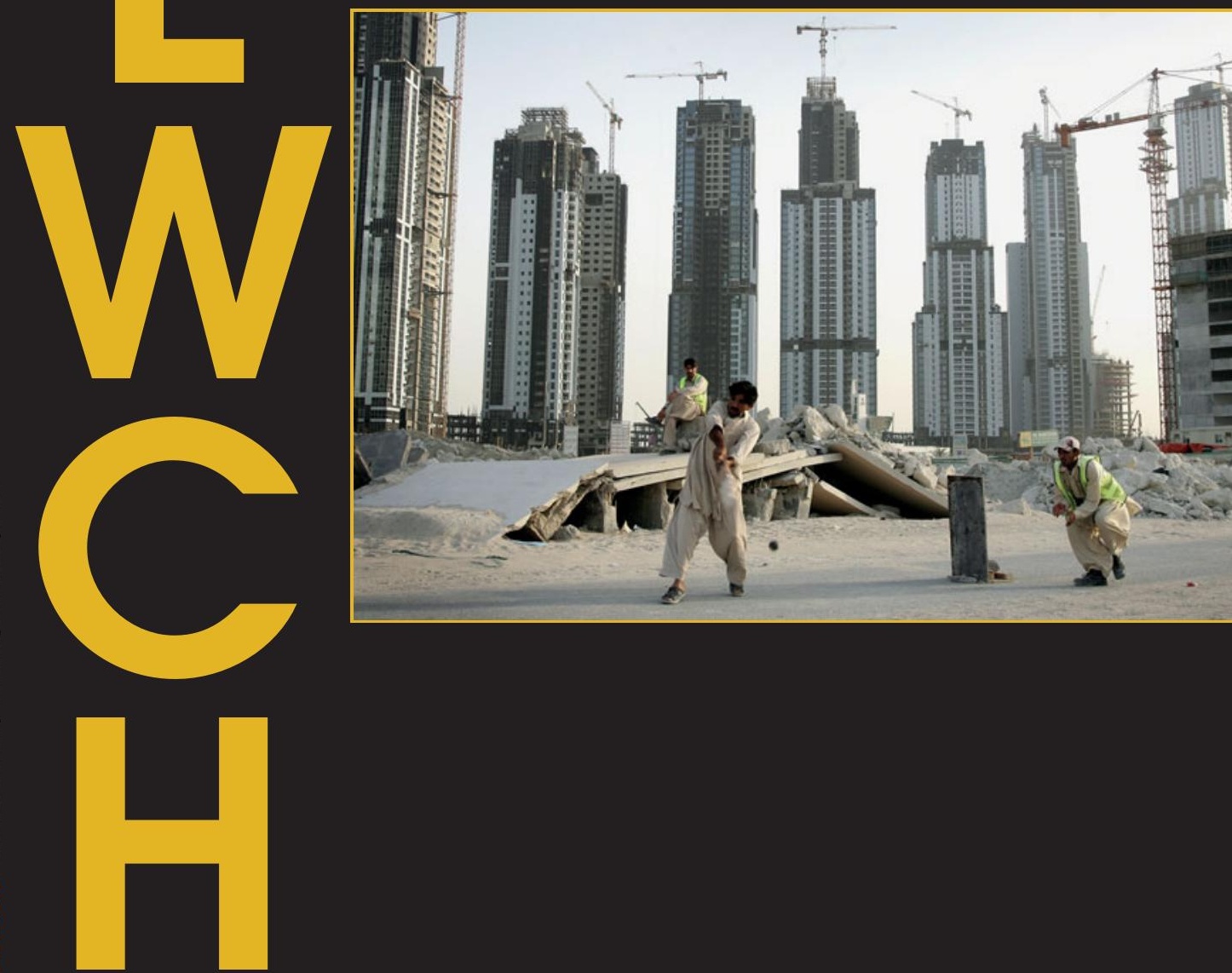


\section{SENIOR EDITORS}

\section{Carolyn Brown \\ Rutgers University}

Jennifer Klein

Yale University

Peter Winn

Tufts University

\section{ASSOCIATE EDITOR}

Marcel van der Linden

International Institute of Social

History, Amsterdam

\section{REVIEW EDITOR}

\author{
Kate Brown \\ University of Maryland, \\ Baltimore
}

\section{MANAGING EDITOR}

Allison Miller
Rutgers University
Dorothy Sue Cobble
Rutgers University

Michael Denning
Yale University Yale University

Geoffrey Field Purchase College, SUNY

\section{Joshua Freeman CUNY Graduate Center}

Michael Hanagan Vassar College

Thomas Miller Klubock University of Virginia

David Montgomery Yale University
EDITORIAL BOARD

Mae Ngai

Columbia University

Mary Nolan New York University

Prasannan Parthasarathi Boston College

Donald Quataert Binghamton University

Gerald Sider College of Staten Island, CUNY

Judith Stein City College, CUNY

Renqiu Yu Purchase College, SUNY

\title{
EDITORS EMERITUS
}

\author{
Helmut Gruber \\ Polytechnic University \\ Ira Katznelson \\ Columbia University
}

International Labor and Working-Class History (ISSN 0147-5479) is published twice yearly, in the spring and the fall, by Cambridge University Press for the editors of $I L W C H$. Additional support is provided by Rutgers University. Annual subscription rates for Numbers 77 and 78 (2010): Institutional subscription rates, print and online: US\$135.00 in the USA, Canada, and Mexico; UK $£ 83.00$ + VAT elsewhere. Institutional subscription rate, online only: US \$112.00 in the USA, Canada, and Mexico; UK $£ 68.00+$ VAT elsewhere. Institutional subscription rate, print only: US \$117.00 in the USA, Canada, and Mexico; UK $£ 71.00$ + VAT elsewhere. Individual subscription rate, print only: US \$48.00 in the USA, Canada, and Mexico; UK $£ 30.00+$ VAT elsewhere. Single part rates, print only: US \$64.00 in the USA, Canada, and Mexico; UK $£ 39.00$ + VAT elsewhere. Prices include surface postage. International Labor and Working-Class History is indexed in ABC-CLIO; Alternative Press Index; American Bibliography of Slavic and East European Studies; America: History and Life; Arts and Humanities Citation Index; Current Contents: Arts and Humanities; Historical Abstracts; Left Index; Middle East: Abstracts and Index; and Sociological Abstracts.

Editorial Office: Manuscripts, editorial correspondence, and books for review should be addressed to Managing Editor, ILWCH, Rutgers University, 50 Labor Center Way, New Brunswick, NJ 08901, USA, or via e-mail: ilwch@work.rutgers.edu

Publishing, Subscription, and Advertising Offices: Cambridge University Press, 32 Avenue of the Americas, New York, NY 10013-2473, USA. Tel: 1-800-872-7423. Fax: 1-212-337-5959; or Cambridge University Press. The Edinburgh Building, Shaftesbury Road, Cambridge CB2 8RU, UK. Tel: +44(0) 223325806. Fax: +44(0)223 315052. E-mail: journals_marketing@cambridge.org. See also http://www.cambridge.org.

Copyright (C) 2011 International Labor and Working-Class History, Inc. All rights reserved. No part of this publication may be reproduced, in any form or by any means, electronic, photocopying or otherwise, without permission in writing from Cambridge University Press. Photocopying information for users in the USA: The Item-Fee Code for this publication (ISSN 0147-5479/11 \$15.00) indicates that copying for internal or personal use beyond that permitted by Sec. 107 or 108 of the US Copyright Law is authorized for duly registered with the Copyright Clearance Center (CCC) Transaction Reporting Service, provided that the appropriate remittance of $\$ 15.00$ per article is paid directly to: CCC, 222 Rosewood Drive, Danvers, MA 01923. Specific written permission must be obtained for all other copying.

The Board of Consulting Editors may be found immediately following the contents. See the back inside cover of the journal for information concerning submissions to the journal.

Cover Image: Construction workers playing cricket, Dubai. Photograph by Chris Jackson/Getty Images. 
In Memoriam: Donald Quataert Michael Hanagan

Senior Editors' Note

Carolyn Brown, Jennifer Klein, and Peter Winn

\section{MIGRANT WORKERS IN THE MIDDLE EAST}

Introduction

Prasannan Parthasarathi and Donald Quataert

The Turn of the Gulf Tide: Empire, Nationalism, and South Asian Labor Migration to Iraq, c. 1900-1935

Stefan Tetzlaff

Migration and Popular Protest in the Arabian Peninsula and the Gulf in the 1950 s and 1960 s

John Chalcraft

Philippine Migrant Workers' Transnationalism in the Middle East

Robyn Magalit Rodriguez

Project-Tied Labor Migration from Turkey to the MENA Region:

Past, Present, and Future

Ahmet Içduygu and Deniz Sert

Where Governmentality Ends: Border Control Officers

and Deportations of Sojourners in Israel

Oded Korczyn

Migration as Diplomacy: Labor Migrants, Refugees, and Arab

Regional Politics in the Oil-Rich Countries

Helene Thiollet

Unofficial Citizens: Indian Entrepreneurs and the State-Effect

in Dubai, United Arab Emirates

Neha Vora

Migration, Neoliberal Capitalism, and Islamic Reform

in Kozhikode (Calicut), South India

Filippo Osella and Caroline Osella 


\section{REVIEW ESSAY}

Emptiness in the Colonial Gaze: Labor, Property, and Nature Robert L. Nelson

\section{ARTICLE}

Differences in Workers' Narratives of Contention in Two Central Indian Towns

Manjusha Nair 


\section{BOARD OF CONSULTING EDITORS}

Risto Alapuro

University of Helsinki

Kathryn Amdur

Emory University

Eric Arnesen

University of Illinois, Chicago

Touraj Atabaki

International Institute of Social History,

Amsterdam

Joel Beinin

Stanford University

Gerd Callesen

Arbejderbevaegelsens Bibliotek og Arkiv,

Copenhagen

Jane Caplan

St. Antony's College, Oxford

Frederick Cooper

New York University

Jefferson Cowie

Cornell University

Patrizia Dogliani

University of Bologna

Geoff Eley

University of Michigan

Elizabeth Faue

Wayne State University

Paulo Fontes

Fundacão Getulio Vargas

John French

Duke University

Patrick Fridenson

Ecole des Hautes Etudes en Sciences

Sociales

Wendy Z. Goldman

Carnegie Mellon University

Andrew Gordon

Harvard University

Linda Gordon

New York University

Rick Halpern

University of Toronto

Victoria Hattam

New School for Social Research
William P. Jones

University of Wisconsin,

Madison

Don Kalb

Central European University

Linda Kerber

University of Iowa

Neville Kirk

Manchester Metro University

Deborah Levenson-Estrada

Boston College

Bruce Levine

University of Illinois,

Champaign-Urbana

Earl Lewis

Emory University

Nelson Lichtenstein

University California, Santa

Barbara

Alf Luedtke

Max-Planck-Institut für Geschichte

Mary Jo Maynes

University of Minnesota

Gwendolyn Mink

Smith College

Mary Nash

University of Barcelona

Silke Neunsinger

Labour Movement Archives

and Library, Sweden

Elizabeth Perry

Harvard University

Anson Rabinbach

Princeton University

Pamela Radcliff

University of California,

San Diego

Dilip Simeon

Association of Indian Labour

Historians

Barbara Weinstein

New York University 

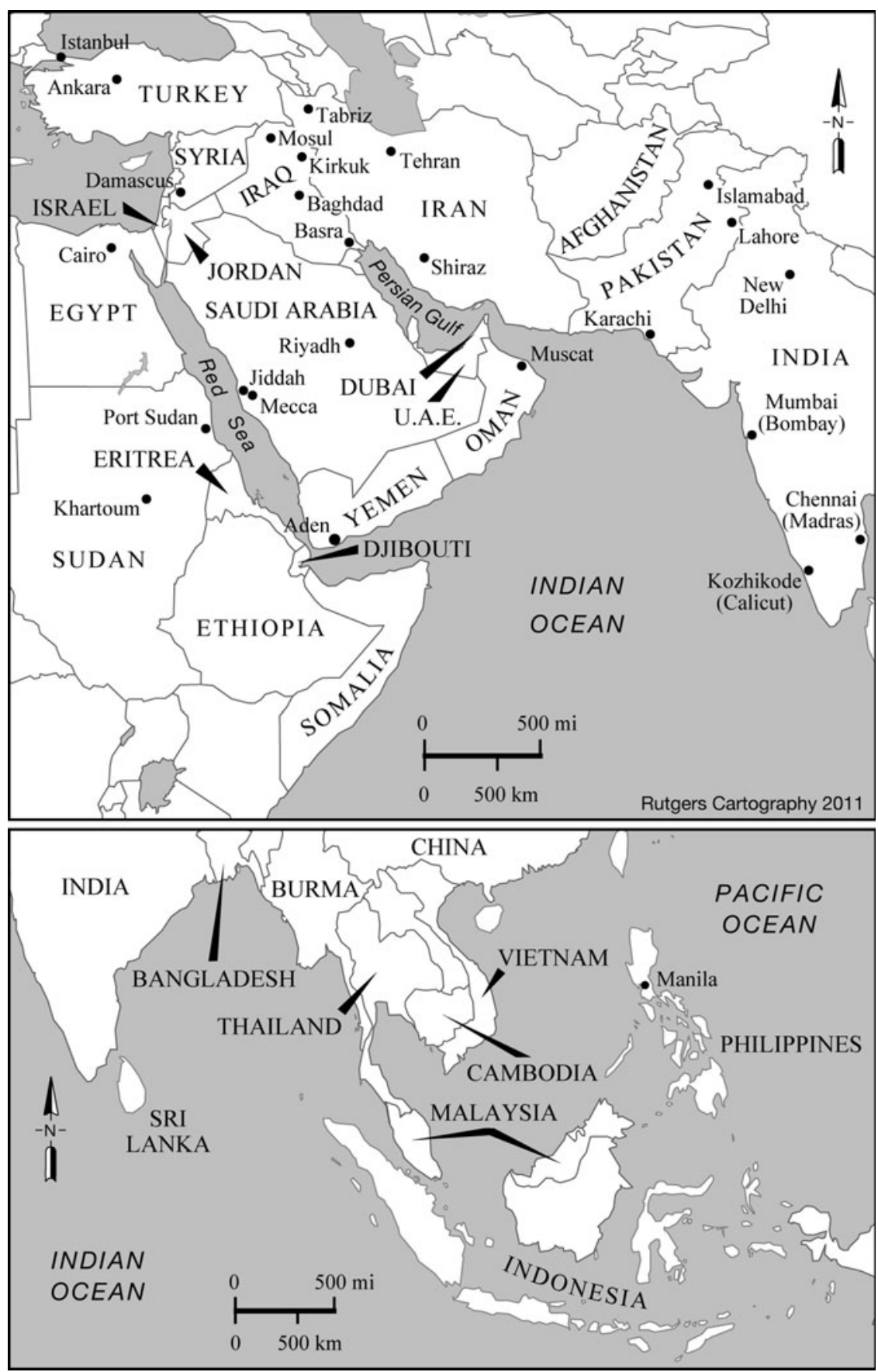
Special Issue

\title{
Labor Migration to the Middle East
}

\author{
This issue of \\ International Labor and Working-Class History \\ is dedicated to the memory of Donald Quataert, coeditor \\ of this special issue and a much-beloved member of the \\ journal's Editorial Board, who passed away as this issue \\ was going to press. He will be sorely missed.
}

